\title{
A REGIONAL ANALYSIS OF U.S. AGRICULTURAL AND MANUFACTURING LABOR MARKET\#
}

\author{
Juei Ming Cheng*

\section{INTRODUCTION}

Within the United States, there are important interregional differences in the absolute levels of money income received by rural residents. There are also significant interregional differences in the spreads between farm and nonfarm earnings. Most previous studies of regional wage differentials have been based on gross comparisons of state income levels, or have examined wages for a few specific industries and occupations. Some investigations [5], [7], [15], have been confined to estimating the magnitude of interregional wage differentials. Others have found considerable value in estimation of production functions for individual industries and the calculation of elasticities of substitution between labor and capital [4], [11]. Still other attempts have been made to identify the factors which have caused and have served to perpetuate wage differentials [7], [14].

The purpose of this study is to identify and estimate the underlying structural demand and supply relations for farm and manufacturing labor forces on a regional basis, and to use these relationships in interpreting the wage disparities and labor supply conditions among the regions between farm and manufacturing sectors. Defined specifically, this paper constructs a simultaneous equation model for the labor market, and uses econometric techniques to point out differences in factors and conditions which affect the demand for and supply of labor among the regions and between the sectors. Using cross-sectional data by state for 1950 and 1960 , the focus is on the classic case of the differences between the South and the non-South.

\section{THE MODEL}

\section{Basic Assumptions}

The observed levels of wages and quantities of labor inputs in different states in different sectors, respectively, are interpreted as equilibrium conditions - that is, points of intersections between the demand for and supply of labor. The model assumes that aggregate output in each sector of

*Department of Economics, Georgia State University, Atlanta, Georgia.

\#The author would like to thank the Bureau of Business and Economic Research of Georgia State University for the time made available to finish this paper. He is also indebted to Samuel L. Skogstad, Edwin Ulveling, and two reviewers for valuable comments. 
each state can be represented by a generalized aggregate production function. Furthermore, the parameters in the production function for each state are regarded as identical. The model assumes that the parameters in the labor supply function in each sector of each state also can be regarded as identical. ${ }^{1}$

\section{The Demand for Labor}

Conventional economic theory, previous research in the area of wage differentials [14], [16], [23], the economics of human capital [1], [13], and the theoretical possibility of wage discrimination against minority labor [6], [8], suggests that the structural demand function for labor in its general form is:

$$
\text { (1) } \mathrm{W}=\mathrm{f}(\mathrm{L}, \mathrm{C} / \mathrm{L}, \mathrm{S}, \mathrm{R})
$$

where $\mathrm{W}$ denotes the average hourly real wage rate paid to production workers (farm or manufacturing); L, labor input; C/L, capital-labor ratio; $\mathrm{S}$, level of schooling; and $\mathrm{R}$, nonwhite as a percent of all production workers (farm or manufacturing). This is a five-dimensional labor demand function, where $\mathrm{W}$ and $\mathrm{L}$ are endogenous and $\mathrm{C} / \mathrm{L}, \mathrm{S}$, and $\mathrm{R}$ are exogenous. The assertion that $\mathrm{C} / \mathrm{L}$ is exogenous is based on the assumption that, in the short run, capital formation precedes the act of demanding labor in the market. The assertion that $\mathrm{S}$ and $\mathrm{R}$ are exogenous stems from the notion that the level of schooling and the color of the labor force are complicated functions of many variables in which sociohistorical factors play the main role.

Let us consider the rationale embodied in (1). Basic economic theory tells us that a firm in a competitive industry will hire workers up to the point where the value of the marginal product just equals the wage of the worker. ${ }^{2}$ If pure competition exists, in order for the regional economy as a whole to "optimize," the condition must be that the real wage rate equals the marginal physical product of labor. The factors of production are remunerated by an amount equal to their respective marginal products:

$$
\mathrm{W}=\frac{\partial \mathrm{X}}{\partial \mathrm{L}}
$$

where X denotes output.

According to the law of diminishing returns, the marginal product of labor declines as more workers are hired. It follows that if the level of employment is to be increased, the real wage rate must fall,

i.e.,

$$
\frac{\partial^{2} \mathrm{X}}{(\partial \mathrm{L})^{2}}<0
$$


This defines the expected sign of the $\mathrm{L}$ variable shown in expression (1).

The relationship between the wage rate (labor productivity) and the capital-labor ratio remains to be shown. We assume the production function, $\mathrm{X}=\mathrm{F}(\mathrm{L}, \mathrm{C})$ is homogeneous of the first degree. We write:

$$
\begin{aligned}
\mathrm{X} & =\mathrm{F}(\mathrm{L}, \mathrm{C}) \\
& =\mathrm{LF}(1, \mathrm{C} / \mathrm{L}) \\
& =\mathrm{Lf}(\mathrm{C} / \mathrm{L})
\end{aligned}
$$

A priori our expectation is that, if the differences in the wage rate are related to differences in the capital-labor ratio, there should be a positive association between the variables,

i.e.,

$$
\frac{\partial \mathrm{W}}{\partial(\mathrm{C} / \mathrm{L})}>0
$$

This defines the expected sign of the $\mathrm{C} / \mathrm{L}$ variable shown in expression (1).

On theoretical grounds the relationship between the wage rate and the level of schooling is the same as that asserted for the physical capital-labor ratio,

i.e.,

$$
\frac{\partial \mathrm{W}}{\partial \mathrm{S}}=\frac{\partial^{2} \mathrm{X}}{\partial \mathrm{S} \partial \mathrm{L}}>0 .
$$

The relationship between racial composition of the labor force and the wage rate is a complicated function of many variables. Scully [14] asserts that a disutility function can be specified for employers who hire minority labor, so the minority segment of the labor force will receive a wage rate less than the marginal product of labor. The differential is determined by the employer's "taste" for discrimination. We assert

that

$$
\frac{\partial \mathrm{W}}{\partial \mathrm{R}}=\frac{\partial^{2} \mathrm{X}}{\partial \mathrm{R} \partial \mathrm{L}}<0,
$$

since the race variable is defined as the ratio of nonwhites to total workers.

In our statistical model, the labor demand function is:

$$
\text { (2) } \mathrm{W}_{\mathrm{ij}}=\beta_{\mathrm{l}} \mathrm{L}_{\mathrm{ij}}+\gamma_{1}(\mathrm{C} / \mathrm{L})_{\mathrm{ij}}+\gamma_{2} \mathrm{~S}_{\mathrm{ij}}+\gamma_{3} \mathrm{R}_{\mathrm{ij}}+\gamma_{4}+\mathrm{u}
$$

where the variables are expressed in logarithms. The subscripts $i$ and $j$ signify farm or manufacturing sector and state, respectively. 


\section{The Supply of Labor}

Following neoclassical exonomic theory and basing upon previous studies in the area of labor supply function [3], [10], it is assumed that the structural supply function for labor in its general form is:

$$
\mathrm{W}=\mathrm{F}(\mathrm{L}, \mathrm{U}, \mathrm{S}, \mathrm{R})
$$

where $\mathrm{W}$ and $\mathrm{L}$, the endogenous variables, represent, as previously, real wage rate and labor input, respectively. $U$, which is predetermined, is the rate of unemployment in each sector, and $\mathrm{S}$ and $\mathrm{R}$, which are also predetermined, denote level of schooling and the race variable. The assertion that $\mathrm{U}$ is predetermined is based on the assumption that the rate of unemployment affects the availability of alternative income opportunities and the quantity of labor available depends on the alternative income opportunities.

In this study, it makes sense to formulate the labor supply problem in two steps: (a) how much labor will be supplied to the state economy-which involves a choice between leisure and other goods and which may have a negative relation between income and level of employment, and (b) given this, how much is supplied to each industry. The latter depends on relative wages, other things equal. It is reasonable to expect that both in the "aggregate" and particular cases the function should be positively sloped. This defines the expected sign of the $\mathrm{L}$ variable shown in expression (3).

This study asserts that the relation between the rate of unemployment in the regional economy and the number of labor units supplied is positive. When the supply of labor increases and other things remain the same, the wage rate will decrease. The interpretation is that the unemployment rate affects the availability of alternative income opportunities. ${ }^{3}$

We assert that workers with more schooling have a relatively higher wage rate. The interpretation of this statement is that workers with more schooling are aware of their advantage and they are in a better position to sell their labor services in the other sector.

We assert that the relation between the racial factor and the wage rate is negative because the race variable was defined as the ratio of nonwhites to total workers.

In our statistical model the supply function is:

$$
\mathrm{W}_{\mathrm{ij}}=\beta_{2} \mathrm{~L}_{\mathrm{ij}}+\gamma_{5} \mathrm{U}_{\mathrm{ij}}+\gamma_{6} \mathrm{~S}_{\mathrm{ij}}+\gamma_{7} \mathrm{R}_{\mathrm{ij}}+\gamma_{8}+\mathrm{v}
$$

where the variables are in logarithms.

This equations system [equations (2) and (4)] is just identified.

4. The Reduced Form and the Regression Form

The reduced form of the model can be expressed by the following:

$$
\begin{aligned}
& \mathrm{W}_{\mathrm{ij}}=-1 / \Delta\left[\beta_{2} \gamma_{1}(\mathrm{C} / \mathrm{L})_{\mathrm{ij}}+\left(\beta_{2} \gamma_{2}-\beta_{1} \gamma_{6}\right) \mathrm{S}_{\mathrm{ij}}+\left(\beta_{2} \gamma_{3}-\beta_{1} \gamma_{7}\right) \mathrm{R}_{\mathrm{ij}}-\beta_{1} \gamma_{5} \mathrm{U}_{\mathrm{ij}}\right. \\
& \left.\quad+\left(\beta_{2} \gamma_{4}-\beta_{1} \gamma_{8}\right)+\left(\beta_{2} \mathrm{u}+\beta_{1} \mathrm{v}\right)\right]
\end{aligned}
$$




$$
\begin{aligned}
\mathrm{L}_{\mathrm{ij}} & =-1 / \Delta\left[\gamma_{1}(\mathrm{C} / \mathrm{L})_{\mathrm{ij}}+\left(\gamma_{2}-\gamma_{6}\right) \mathrm{S}_{\mathrm{ij}}+\left(\gamma_{3}-\gamma_{7}\right) \mathrm{R}_{\mathrm{ij}}-\gamma_{5} \mathrm{U}_{\mathrm{ij}}+\left(\gamma_{4}-\gamma_{8}\right)\right. \\
& +(\mathrm{u}+\mathrm{v})]
\end{aligned}
$$

where $\Delta=\beta_{1}-\beta_{2}$.

Next, it is necessary to postulate the regression form. The regression model is defined by the system of equations:

$$
\begin{aligned}
& \mathrm{W}_{\mathrm{ij}}=\alpha_{1}(\mathrm{C} / \mathrm{L})_{\mathrm{ij}}+\alpha_{2} \mathrm{~S}_{\mathrm{ij}}+\alpha_{3} \mathrm{R}_{\mathrm{ij}}+\alpha_{4} \mathrm{U}_{\mathrm{ij}}+\alpha_{5}+\eta_{\mathrm{ij}} \\
& \mathrm{L}_{\mathrm{ij}}=\alpha_{6}(\mathrm{C} / \mathrm{L})_{\mathrm{ij}}+\alpha_{7} \mathrm{~S}_{\mathrm{ij}}+\alpha_{8} \mathrm{R}_{\mathrm{ij}}+\alpha_{9} \mathrm{U}_{\mathrm{ij}}+\alpha_{10}+\delta_{\mathrm{ij}}
\end{aligned}
$$

Although the magnitudes of the coefficients of the regression forms remain to be determined by the data, the coefficients are expected to have a certain sign if the theoretical restrictions discussed in the previous sections are satisfied. If the theoretical restrictions hold, then $\alpha_{1}, \alpha_{2}, \alpha_{6}$ and $\alpha_{9}$ should be positive, $\alpha_{3}$ and $\alpha_{4}$ should be negative, and $\alpha_{7}$ and $\alpha_{8}$ have an ambiguous sign.

After equations (5) and (6) are estimated in each region of both sectors, the coefficients of the structural equations (2) and (4) can be calculated.

\section{EMPIRICAL RESULTS}

The previous discussion provides a basis for empirical testing of the hypothesis embodied in expressions (5) and (6). The results of fitting the reduced forms (5) and (6) to 1950 and 1960 data for each region ${ }^{4}$ and each sector are given in Table 1 and Table 2. Since the data consist of 1950 and 1960, we introduce dummy variables for 1950 and 1960..$^{5}$ Table 1 and Table 2 indicate that the estimates are all consistent with the theory in terms of the predicted signs except two. If we consider the whole estimating equation, 12 out of 16 equations are significant at the one percent level, at least. One regression equation each is significant at the 2.5 percent and 5 percent levels. A possible reason for insignificance of some of the coefficients in the separate region-sector equations may be the small size of the number of observations. Table 3 contains the equations for South and non-South results in each sector. As Table 3 shows, all of the coefficients of the independent variables are significant, at least at the 10 percent level, except one. In general, the indication is that the hypotheses embodied in expressions (5) and (6) explain a very considerable portion of interstate variations in farm and manufacturing wage rates and conditions of labor supply.

Estimates of the structural parameters are shown in Table 4.

The regression and structural results for the sector and region equations permit the following conclusions about interstate wage variations and different labor supply conditions. (1) The most important explanatory variable is the level of schooling. The level of schooling variable is significant (at least at the 10 percent level) in 15 of the 16 region-sectors. The 


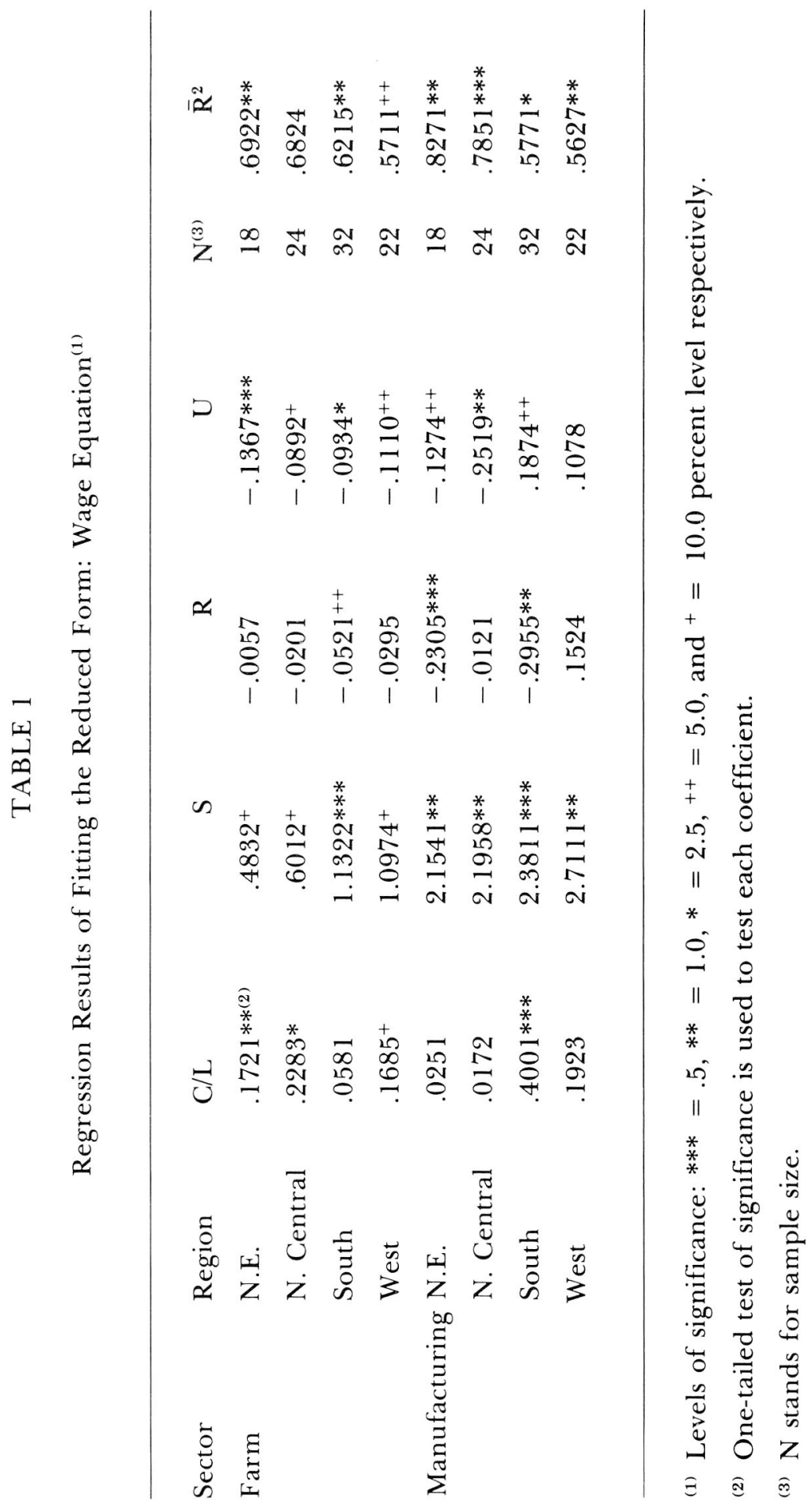




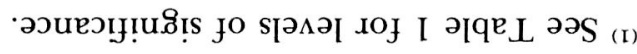

\begin{tabular}{|c|c|c|c|c|c|c|c|}
\hline ** I 968 & 66 & $* * I G \nsubseteq 0 \cdot \mathrm{I}$ & $* * * 6097-$ & $++\angle 698^{\circ} \mathrm{I}-$ & $+8.969^{\circ}$ & $\operatorname{ls} \partial M$ & \\
\hline$* * 6 \angle 98^{\circ}$ & 38 & $+9 Z 6 \mathrm{I}^{\circ}$ & $+I_{90 \sigma^{\circ}-}$ & $* * 8686^{\circ} \mathrm{I}-$ & $* * * 9 \angle 89^{\circ}$ & yłnos & \\
\hline$* * \mp \angle \sigma L$ & $\pm z$ & $I \angle L 6$ & $+6689^{\circ}$ & $50 \angle 9^{\circ}-$ & $* 6867$ & [ел]иว弓 'N & \\
\hline$* * * L I L 6$ & $8 \mathrm{I}$ & $* * \angle \angle 9 \angle$ & $60 \angle 0^{\circ}$ & ${ }_{++}^{+} 6$ I $\zeta 8^{\cdot-}$ & $+89 \angle \sigma^{\circ}$ & $\cdot \mathrm{A} \cdot \mathrm{N}$ & ejnuew \\
\hline$* * * 69<8$ & 66 & $* G \angle 8 B^{\circ}$ & $++996 \mathrm{I}^{\circ}-$ & ${ }_{++} \mathrm{I} L 6 \nabla^{\circ} \mathrm{I}-$ & $++\not \angle 88^{\circ}$ & 1 səa $M$ & \\
\hline$* * * \operatorname{II} t L$ & 68 & $* * G \angle 98$ & $++\mp G \varepsilon I^{\circ}$ & ${ }_{++} 69 \& L I-$ & $+69+I^{\circ}$ & yinos & \\
\hline $96 \angle t^{\circ}$ & $\pi \sigma$ & $+8 I_{9 g^{\circ}}$ & $6690^{\circ}-$ & $++\angle I 60^{\circ} \mathrm{I}-$ & $8 \angle 9 I^{\circ}$ & [ел]uว’ $\mathrm{N}$ & \\
\hline$* *$ I 898 & $8 \mathrm{I}$ & $+9966^{\circ}$ & I $6 \angle 0^{\circ}-$ & $* G I 9 L-$ & $* * \pm\left[\zeta 8^{\circ}\right.$ & $\cdot \mathrm{A} \cdot \mathrm{N}$ & wute \\
\hline${ }_{z} \underline{\mathrm{d}}$ & $\mathrm{N}$ & $\Omega$ & $y$ & S & $\mathrm{T} / \mathrm{O}$ & uoเ̣ภว & Іоџวэ \\
\hline
\end{tabular}

(г) Uo!̣enb

б 月าด $\forall \mathrm{L}$ 


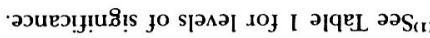

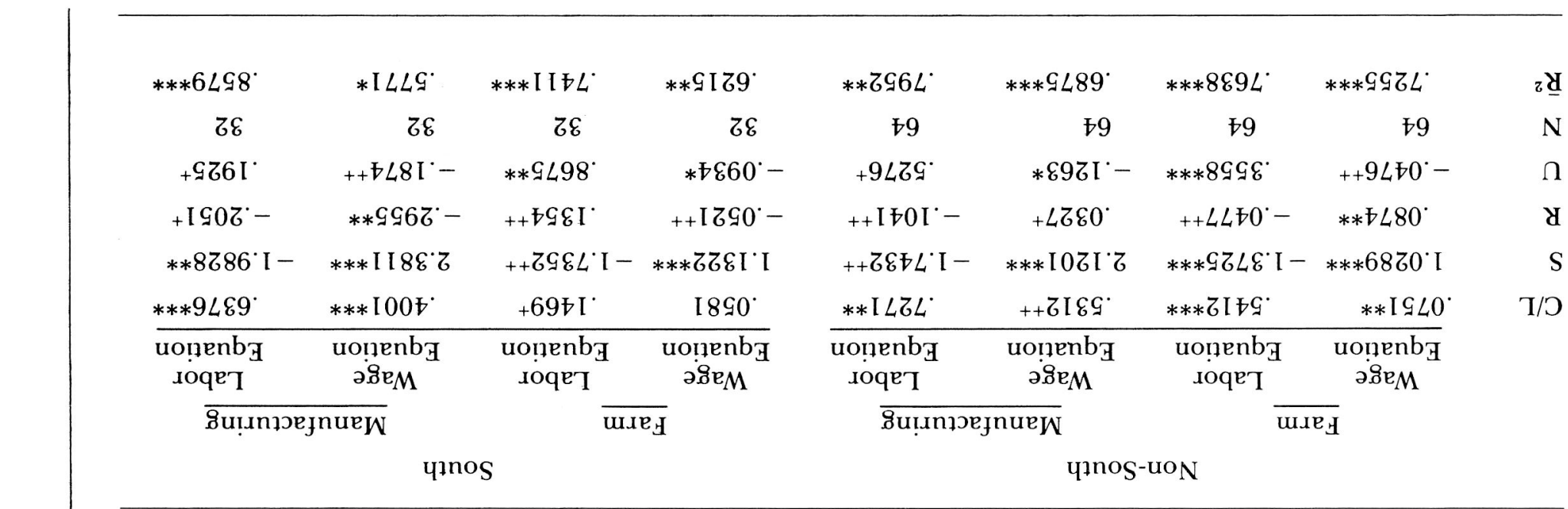

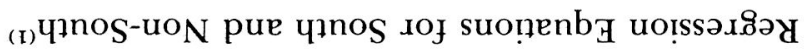

\& สาดทI 


\section{TABLE 4}

Point Estimates of the Coefficients of the Structural Equations

\begin{tabular}{llrrrr} 
Sector & Region & \multicolumn{4}{c}{ Demand } \\
& & $\mathrm{L}$ & $\mathrm{C} / \mathrm{L}$ & $\mathrm{S}$ & $\mathrm{R}$ \\
Farm & N.E. & -.6062 & .6211 & .1369 & -.0472 \\
& N. Central & -.2536 & .2932 & .3481 & -.0467 \\
& South & -.1075 & .1459 & .9723 & -.0545 \\
& West & -.2315 & .2397 & .6125 & -.0976 \\
& Non-South & -.1338 & .2378 & .7726 & .0845 \\
Manufacturing & N.E. & -.1658 & .0843 & 1.9526 & -.2134 \\
& N. Central & -.9089 & .4667 & 2.2716 & .1637 \\
& South & -.9734 & .4273 & 1.4218 & -.4863 \\
& West & -.1031 & .0681 & 2.9057 & .0774 \\
& Non-South & -.2394 & .5129 & 1.3265 & .0581 \\
& & & & & \\
Sector & Region & & & Supply & \\
& & $\mathrm{L}$ & $\mathrm{U}$ & $\mathrm{S}$ & $\mathrm{R}$ \\
& N.E. & .2095 & -.1853 & .2747 & -.0168 \\
& N. Central & 1.3645 & -.5246 & 2.1627 & -.0894 \\
& South & .3958 & -.2357 & 1.5364 & -.0855 \\
& West & .4921 & -.2637 & 1.7211 & .0357 \\
& Non-South & .1384 & -.0741 & 1.0507 & .0873 \\
& N.E. & .0975 & -.1342 & 2.5413 & -.1894 \\
& N. Central & .0406 & -.2176 & 2.2981 & -.1021 \\
& South & .6275 & -.2433 & 2.8655 & -.2465 \\
& West & .3654 & -.2287 & 2.9225 & .1605 \\
& Non-South & .7306 & -.1264 & 2.4256 & .0768 \\
& & & & & \\
\hline
\end{tabular}

interesting explanation of these results is that to raise the level of schooling of people will increase the mobility of the labor force. Moreover, additional schooling also increases the economic productivity of the labor force in farm and manufacturing. (2) The rate of unemployment in each sector constitutes an important explanatory force in farm as well as manufacturing wage and employment conditions. The unemployment variable is significant in 14 of the 16 cases. The result supports the hypothesis that the rate of unemployment increase will decrease the real wage rate in general and increase the supply of labor. (3) The capital-labor ratio does not emerge, at least at the region-sector as a whole, as an important source of regional wage variation, but it explains moderately well in the labor de- 
mand condition. (4) The results of the non-white variable are unclear when we consider the region-sector as a whole.

If we compare the magnitude of the structural coefficients in South and non-South, in the same sector, and in farm and manufacturing in the same region, the results are also of interest. The coefficients for the level of schooling in the demand equation vary. In general, the values of the coefficients are higher in the Southern region equations than in the nonSouth region equations. In the farm sector, the values of the coefficients for South and non-South are 0.9723 and 0.7726 and in the manufacturing sector are 1.4218 and 1.3265 . This indicates that increases in the level of schooling have a greater impact in raising wage rates in the South than in the other regions, in both the farm and the manufacturing sectors. ${ }^{6}$ This result is consistent with Becker and Chiswick's [2], Hanoch's [9], and Scully's [14]. When we look at the coefficients for the level of schooling in the supply equation, the values of the coefficients are higher in the South than in the non-South. The coefficients for farm, South and non-South, are 1.5364 and 1.0507 , and 2.8655 and 2.4256 for manufacturing. This indicates that workers with more schooling are aware of their advantage and they are in a better position to sell their labor services in the other sector, and will accelerate the process of outmigration and reduce the supply of labor in the South more than in other areas [8]. Comparing the farm and manufacturing sectors in the same region, we found that manufacturing coefficients are higher than farm coefficients. This means that more schooling has a greater impact in the manufacturing sector than in the farm sector in terms of raising the wage rates and labor mobility.

The coefficients for the capital-labor ratio are similar in sign in both regions. In fact, there is a larger impact of changes in the capital-labor ratio with respect to changes in the wage rate in the non-South. The coefficient of the capital-labor ratio is higher in the non-South, suggesting higher relative returns to capital formation in the non-South. The effect of the capital-labor ratio is to create a wage differential unfavorable to the South. In both areas, the effect of the capital-labor ratio on the wage rate is higher in manufacturing than in the farm sector.

The most clear difference in the coefficients is that of the race variable. The signs of the coefficients in the non-South area indicate that the white-nonwhite wage differential does not exist in the non-South areas. But wage discrimination against nonwhites does appear in the South.

The coefficients of the rate of unemployment variables support the hypothesis that as the rate of unemployment increases the wage rate will decrease. This situation is more serious in the South than in the non-South and more serious in the manufacturing sector than in the farm sector. This suggests that when a laborer compares his farm and nonfarm earnings, he forms an expected value of the nonfarm earning possibilities based on their pecuniary earnings if employed, and the possibility of being unemployed. This suggests that the different earnings between the two sectors and among the regions could be sufficient to compensate for the possibility of being unemployed [12] 


\section{CONCLUSIONS AND POLICY IMPLICATIONS}

Our statistical results have indicated considerable variation among the regions between the sectors with respect to the demand and supply of labor. The empirical results establish a substantial confirmation of our basic hypotheses, which have been advanced as interpretations and identifications of interregion wage variations and labor supply conditions between farm and manufacturing sectors. At the regional level, in a limited way, the hypotheses are consistent with our theoretical expectations. But even more conclusive results are obtained with South-non-South aggregated equations. All four of the explanatory independent variables are highly significant in the statistical sense in agricultural and manufacturing sectors.

Perhaps the most interesting aspect of the results is the implication that they have for the prospects of obtaining regional wage uniformity. Fairly clearly, such uniformity will depend rather heavily upon (1) the extent to which the North-South differences in the level of schooling are eliminated, (2) the elimination of the barriers to the free flow of factors of production among the regions, and (3) the elimination of the white-nonwhite wage differential. Unfortunately, these are not events which one would expect to occur in the course of the normal operation of the market place. It would seem from our evidence that the factors which would be most likely to produce such uniformity are political and social in character rather than economic.

The coefficients of level of schooling are higher in the South, suggesting higher relative returns to education in the South. The effect of level of schooling has a greater impact in raising the productivity of labor and accelerating the process of labor outmigration in the South than in the other areas. Southern labor with poor education finds it difficult to compete against non-South labor, and is thus discouraged from moving to other regions. The federal government subsidizes public education in the elementary and secondary schools and special job training in rural farm areas and in the Southern states which, in the long run, will increase farm income and accelerate the process of farm outmigration significantly. It is interesting to note that present education and manpower policies of the federal government and affirmative action programs are consistent with such objectives, and though not specifically designed to do so, may contribute more to solving the secular low-income problem in agriculture and Southern states.

The effect of the capital-labor ratio is to produce a favorable condition to the non-South and to the manufacturing sector with respect to changes in wage rates and demand for labor. The results of this study suggest that differing factor proportions, sustained in the long-run by barriers to the free interregional flow of factors of production, is the one important cause of the wage differentials in the South and in the farm sector. The development of the "sun belt" will encourage the free flow of factors of production among the regions and should improve the regional wage uniformity significantly. 
The statistical results also confirm that a white-nonwhite wage differential has existed in the South in both the farm and manufacturing sectors. As to the white-nonwhite wage gap, whether the wage variation is due to productivity differential, we cannot answer in this study. We assume that the racial wage differential as it now exists is primarily explained by noneconomic factors. The white-nonwhite wage gap is perhaps the most intractable problem facing our society today and, if it is to be eliminated, clearly involves social and political decisions of the first magnitude.

Finally, the elasticities associated with the rate of unemployment variable imply that there is a continuing oversupply of labor in agriculture and in the Southern region. This is one reason why efforts should be directed specifically to the transfer of labor resources to the nonfarm sector and non-South regions. The seriousness of this problem varies from region to region; therefore, policies should be directed at particular regions that have an excess labor problem, rather than at the U.S. as a whole, and should be tailored to fit the individual situation. The development of the "sun belt," which will generally improve economic conditions in the South, should alter these relationships significantly.

The South-non-South wage differential as it now exists is primarily non-economic in character, arising out of a political and social milieu which is not particularly amenable to elimination by the normal operation of the labor market. This wage differential is likely to continue until basic decisions are made in the political and social arenas which will eliminate these factors in our society.

\section{APPENDIX:}

\section{Data Description}

\section{Real Wage Rate}

The real wage rate is the money wage deflated by the consumer price index. Annual average composite farm wage rates per hour are available by states in different issues of Farm Labor, published by the U. S. Department of Agriculture. The average hourly wage rate paid to production workers in manufacturing is available by states in the Statistical Abstract of the U.S. ${ }^{7}$

\section{Labor Input}

Farm labor services are supplied by farm operators and their families, and hired farm workers. Because many farmers spend part of their time working off farms, employment data is not a good proxy for labor inputs of farms. In this study, farm labor input of family was obtained by multiplying family employment by the number of days worked per operator, and the total number of days worked by hired farm labor was obtained by dividing the expenditures on hired farm labor by the average daily wage rates. Data about annual average farm family employment is available in Farm Labor. The distributions of farm operators' off-farm work are avail- 
able in the 1959 Census of Agriculture, Volume II, for each state respectively. ${ }^{8}$ Expenditures on hired farm labor are available by states in Farm Income, published by USDA.

Manufacturing labor input was obtained by multiplying the annual average number of manufacturing production workers by the number of days worked per worker. These data are available in the Statistical Abstract of the U.S.

\section{Capital Formation}

Capital formation data of farm by state are nonexistent. The estimates of the value of capital services and current expenditures are used as a proxy for farm capital formation. The estimates of this proxy per year are: (1) repairs, maintenance, and operation of capital items, ${ }^{9}$ and (2) changes, depreciation and other consumption of farm capital. These data are available by state in State Estimates of Farm Income, 1949-1967, FIS-211 (Supplement).

Manufacturing expenditure for new plant and equipment is used as a proxy for manufacturing capital formation. Manufacturing capital formation for each state is calculated from 1953 and 1963 Statistical Abstract of the U.S. ${ }^{10}$

\section{The Level of Schooling ${ }^{11}$}

Median years of school completed by those 25 years of age and older in rural farm areas is used as a proxy for the level of schooling of workers on the farm. Data on schooling in rural farm areas are not available separately for those who work on the farm and those who work off the farm. Median school years completed by 25 years of age and older in urban areas is used as a proxy for the level of schooling of manufacturing workers. Data on schooling are not available separately for manufacturing workers and nonmanufacturing workers. The source is the Census of the Population. ${ }^{12}$

\section{Race Variable}

The race variable for farm sector is the ratio of nonwhite workers in the farm employment to total farmers, farm managers, farm laborers and foremen. And the race variable for manufacturing is the nonwhite manufacturing workers as a percent of the manufacturing labor force. These data are calculated from the Census of the Population. ${ }^{13}$

\section{Unemployment}

The rate of unemployment is included in the supply model as a correction for the alternative income concept. The number of unemployed in rural areas and the number of unemployed in urban areas are used as the proxies for the amount of unemployment in each sector. The source is the Census of the Population. ${ }^{14}$ The rate of unemployment is obtained by dividing the amount of unemployment by the labor input. 


\section{FOOTNOTES}

'This means identical production techniques and elasticities of factor substitution and identical rates of leisure-income substitution.

${ }^{2}$ This is the well known first order condition (necessary condition) for maximizing profit.

${ }^{3}$ The inclusion of the alternative wage in the other sector as another variable is to explain the interrelationship between the labor market. Introducting alternative wage into the model as a separate variable was tried but its coefficients turned out not statistically significant in each sector.

${ }^{4}$ In this study we divide into four regions: North-East, North Central, South, and West. North-East area is: Maine, New Hampshire, Vermont, Massachusetts, Rhode Island, Connecticut, New York, New Jersey, Pennsylvania; North Central area: Ohio, Indiana, Illinois, Michigan, Wisconsin, Minnesota, Iowa, Missouri, North Dakota, South Dakota, Nebraska, Kansas; South area: Delaware, Maryland, Virginia, West Virginia, North Carolina, South Carolina, Georgia, Florida, Kentucky, Tennessee, Alabama, Mississippi, Arkansas, Louisiana, Oklahoma, Texas; West area: Montana, Idaho, Wyoming, Colorado, New Mexico, Arizona, Utah, Nevada, Washington, Oregon, California.

${ }^{5}$ Ten years is a long time to assume structural consistency. Dummy variable is 0 for 1950 data and dummy is 1 for 1960 data. The dummy 1950-1960 variable does not appear in the reported questions.

${ }^{6}$ As Table 3 shows, the coefficients for $\mathrm{S}$ in the nonSouth and South farm equations are quite similar. In fact, there is a slightly larger impact of changes in $S$ with respect to changes in the mobility of the labor force and the economic productivity of the labor force in the South than in other areas.

${ }^{7}$ U. S. Department of Commerce, Statistical Abstract of the U.S., 1956, Table 265, and Ibid., 1963, Table 313.

${ }^{8}$ This is an estimate per operator rather than per member of his family. The assumption was made that on the whole, family employees divided their work just like operators did.

${ }^{9}$ This item includes repairs and maintenance of buildings, repairs and operation of motor vehicles and other machinery, and petroleum fuel and oil used in the farm business.

${ }^{10}$ For 1950, Statistical Abstract of the U.S., 1953, Table 949; for 1960, Ibid., 1963, Table 1105.

${ }^{11}$ The schooling variable takes two forms: the quantity of schooling; second, the quality of schooling (expenditures per enrolled pupil, race, age, sex, etc.). For the purpose of this study only the former is considered. It is believed that the quality of schooling on an intersector basis would be difficult in view of the paucity of data. On the other hand, race variable is included as another variable in order to eliminate a possible bias in the coefficient of schooling.

${ }^{12} 1950$ Census of the Population, Vol. II, Table 65 for each state. 1960 Census of the Population, Vol. II, Table 58 for each state.

${ }^{13} 1950$ Census of the Population, Vol. II, Table 77 for each state. 1960 Census of the Population, Vol. II, Table 58 for each state.

${ }^{14} 1950$ Census of the Population, Vol. II, Table 25 for each state. 1960 Census of the Population, Vol. II, Table 52 for each state.

\section{REFERENCES}

1. G. S. Becker, Human Capital, New York, 1964.

2. G. S. Becker and B. R. Chiswick, "Education and the Disbtribution of Earnings," American Economic Review, May 1966, pp. 358-69.

3. P. H. Douglas and E. Schoenberg, "Studies in the Supply Curve of Labor," Journal of Policitcl Economy, February 1937.

4. C. E. Ferguson, "Cross-section Production Functions and the Elasticity of Substitution in American Manufacturing Industry," Review of Economics and Statistics, August 1963.

5. V. R. Fuchs and R. Perlman, "Recent Trends in Southern Wage Differentials," Review of Economics and Statistics, August 1960, 42, pp 292-300.

6. Victor R. Fuchs, "Differentials in Hourly Earnings by Region and City Size," 1959, Occasional Paper 101 NBER, 1967.

7. L. E. Gallaway, "The North-South Wage Differentials," Review of Economics and Statistics, August 1963, 45, pp. 264-72.

8. Micha Gisser, "Schooling and the Farm Problem," Econometrica, July 1965, pp. 582-592.

9. Giora Hanoch, "An Economic Analysis of Earnings and Schooling," Journal of Human Resources, Summer 1967, pp. $310-29$

10. C. D. Long, The Labor Force Under Changing Income and Employment, NBER, No. 65, General Studies, 1958.

11. Jora R. Minasian, "Elasticities of Substitution and Constant Output Demand Curve for Labor," Journal of Policital Economy, June 1961.
12. G. Edward Schuh, "An Econometric Investigation of the Market for Hired Labor in Agriculture," Journal of Farm Economics, May 1962.

13. T. W. Schultz, "Investment in Human Capital," American Economic Review, March 1961, 51, pp. 1-17.

14. Gerald W. Scully, "Interstate Wage Differentials: A Cross Section Analysis," American Economic Review, December 1969, pp. 757-773.

15. M. Segal, "Regional Wage Differentials in Manufacturing in the Postwar Period," Review of Economics and Statistics, May 1961, 43, pp. 248-55.

16. George G. Sisler, "Regional Differences in the Impact of Urban-Industry Development on Farm and Nonfarm Income," Journal of Farm Economics, December 1959

17. U. S. Bureau of the Census, Census of Agriculture, 1959, Washington.

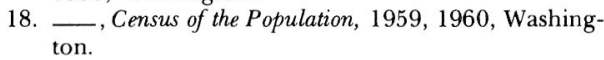

19. U. S. Department of Agriculture, Farm Income, Washington

20. _ Farm Labor, Washington.

21. __ State Estimates of Farm Income, 1949-1967, Washington.

22. U. S. Department of Commerce, Statistical Abstract of the U.S., 1953, 1956, 1960, 1963, Washington.

23. Robert J. Wolfson, "An Econometric Investigation of Regional Differentials in American Agricultural Wages," Econometrica, 1958, pp. 225-257. 